\title{
KREATIVITA A ZNALOSTI - KLÍČ K ÚSPĚCHU
}

\author{
Jan Žahour
}

\section{Klíčová slova:}

Aktiva, data, firma, informace, inovace, manažer, motivace, nápad, plat, prostředí, rozhovor, sdílení, tvořivost, zaměstnanec, znalosti

\section{Key words:}

Assets, data, company, information, innovation, manager, motivation, idea, salary, environment, interview, sharing, creativity, employee, knowledge

\begin{abstract}
Abstrakt
Podniky v současné době kladou stále větší důraz na tzv. řízení znalostních pracovníků. Začaly si uvědomovat, že takový pracovník je to nejcennější, čím může podnik disponovat. Znalostní pracovníci disponují širokou škálou znalostí, a tak by mělo být v zájmu každého podniku si takové zaměstnance hýčkat a považovat, protože jedině tak zabezpečí jejich spokojenost. Ti pak nebudou znalosti zadržovat a budou je sdílet se svými kolegy. Proto je nutné nastavit takový motivační systém ve společnosti, který bude k takovému chování všechny zaměstnance vybízet a podporovat. Jsou to totiž většinou právě znalostní pracovníci, kteří přicházejí s novými nápady, které mohou vyústit až v inovaci, která může být pro podnik průlomová. Cúlem tohoto článku je vyzdvihnout důležitost lidského faktoru, jako nejcennějšího zdroje, kterým může firma disponovat, dále charakterizovat proinovační prostředí ve firmě a pomocí metody neřízeného rozhovoru ověřit, zda faktory, které působí proti kreativnímu myšlení, se vyskytují i ve společnosti, ve které autor působí.
\end{abstract}

\begin{abstract}
Today, the companies place emphesis on the management of knowledge workers. They began to realize that such a worker is the most valuable asset, that a company can have. Knowledge workers have a broad range of knowledge and the company should take care of them and satisfy them. They will not retain the knowledge and will share them with their colleagues. Therefore, it is necessary to set such an incentive system in the company, that would encourage all employees in a such behavior. They are the ones who come up with new ideas that can lead to the innovation that can be a breakthrough for the company. This article aims to highlight the importance of the human factor, as most precious resource, which the company may have, further describe the pro-innovation environment in the company and using the uncontrolled interview to verify whether the factors that counteract creative thinking, occur even in a company which the author works in.
\end{abstract}

\section{Úvod}

Současným světem hýbou inovace. Každý podnik, který chce být úspěšný, inovuje. Inovací se rozumí vytvoření něčeho nového. Jedině podniky, které inovují, mají šanci na přežití. Pouze výrobek, či služba, které se odlišují od současné nabídky, mohou podniku zajistit konkurenční výhodu v podobě vyššího zisku a podílu na trhu. Vše umocňuje fakt, na který poukazuje Smith [19]: „Nejvíce inovativní firmy generují 75\% svých tržeb z výrobků nebo služeb, které 
ještě před pěti lety neexistovaly."Stále větší důraz se rovněž klade na řízení tzv. znalostních pracovníků, protože to jsou právě oni, kdo tvoří ta nejcennější aktiva podniku. Mládková [12] charakterizuje znalostní pracovníky následně:

Tvoří cca polovinu až dvě třetiny pracovníků v rozvinutých zemích

$>$ Při práci používají více mozek

$>$ Vydělávají si na živobytí tím, že myslí

$>$ Učí se stále novému

$>$ Jsou vysoce motivováni, chtějí se neustále zdokonalovat

$>$ Rádi řeší problémy a pracují samostatně

$>$ A PŘEDEVŠÍM FUNGUJÍ JAKO FIREMNÍ ZDROJE KREATIVITY

Schopnosti vytvářet nápady, které jsou originální, jsou dnes nesmírně cenné a jsou považovány za základní a nejdůležitější organizační zdroje při vytváření udržitelné konkurenční výhody [3]. Jaký je však rozdíl mezi kreativitou, dobrým nápadem a inovací? Otcem teorií inovací je Rakušan Joseph A. Schumpeter, který ve svém díle „Teorie hospodářského vývoje“ z roku 1911 charakterizoval inovaci jako ekonomicky aplikovanou invenci, což je praktické převedení nápadu či myšlenky do reality [21]. Myšlenka tak není pouze na papíŕe, nebo v hlavě v podobě nápadu, ale je realizovaná.

Zjednodušeně tak lze říci, že inovace je víc než pouhá myšlenka nebo nápad. Je to implementace, uvedení nápadu $\mathrm{v}$ život. Nedá se zaměňovat s kreativitou. Kreativita je v podstatě dovednost, zatímco inovace představuje proces, který začíná nápadem nebo představou a poté následují různé stupně vývoje, které vyústí do samotného uvedení „do života“. Jak idea, tak kreativita jsou jistě nedílnými součástmi inovace, nicméně ani jedna $\mathrm{z}$ nich sama o sobě nepostačuje $\mathrm{k}$ úspěšnému rozvinutí tvůrčí myšlenky $\mathrm{k}$ naplnění inovace [14].

První část textu se zabývá daty, informacemi a především znalostmi. V současných podnicích je jedním z největších problémů nesdílení znalostí. Pro firmu je tak každý odchod znalostního pracovníka velmi citlivý, jelikož za něj nemusí mít adekvátní náhradu. Ve druhé části textu je pozornost věnována kreativitě, jelikož právě kreativita jedince hraje klíčovou roli při vymýšlení nového výrobku. Třetí část popisuje tzv. proinovační prostředí, čtvrtá část textu uvádí bariéry, které se v podniku mohou vyskytovat. Pátá část textu obsahuje výzkum provedený ve společnosti, kde autor působí, jehož cílem bylo zjistit, zda bariéry, které působí proti kreativnímu myšlení, se vyskytují i v této společnosti. V článku je užívaný název společnosti Alfa s.r.o. Jedná se však o smyšlený název - firma, ve které autor pracuje a která je předmětem tohoto článku, nepovoluje zveřejňovat interní informace.

Cílem tohoto článku je vyzdvihnout důležitost lidského faktoru, jako nejcennějšího zdroje, kterým může firma disponovat, dále charakterizovat proinovační prostředí ve firmě a pomocí metody neřízeného rozhovoru oveřiit, zda faktory, které působí proti kreativnímu myšlení, se vyskytují i ve společnosti, ve které autor působí.

\section{Znalosti}

Většina organizací v současné době považuje znalosti za strategický zdroj, neméně důležitá je rovněž schopnost využít tyto znalosti pro strategické rozhodovací procesy [9]. Je však třeba rozlišovat mezi pojmy: data, informace a znalosti. 
Mládková [12] využívá pro vystižení znalostí definic Vebera [21], který se ke znalostem dopracovává postupně. Nejdříve definuje data jako vše, co můžeme zachytit svými smysly. Za informace považuje data, kterým jejich uživatel při jejich interpretaci přiřazuje důležitost a význam. Informace tak představují určitý typ zprávy nebo př́běhu a je to uživatel, kdo se rozhoduje, zda data, která dostal, jsou informace [21]. Hodnotu informace pro manažera určuje řada faktorů. R. Andrus viz. [2] navrhnul čtyři základní kritéria:

Forma - čím více se forma přibližuje požadavkům manažera, který informaci potřebuje ke svým rozhodnutím, tím se hodnota informace zvyšuje

$>$ Čas - požadované informace je třeba dostat včas (pokud by se tak nestalo, může to mít pro podnik neblahé následky), proto se využívají informace online

$>$ Dostupnost - informace musí být průběžně k dispozici, online systémy tento požadavek splňují

$>$ Vlastnictví - vlastník informace ovlivňuje hodnotu informace tím, že rozhoduje o tom, kdy a komu bude informace poskytnuta; někteří lidé ve společnosti by měli mít dobrý prrehled o tom, kde se požadované informace vyskytují, jak se získávají, zpracovávají, distribuují nebo využívají ostatními

Pokud jsou informace využívány efektivně (kombinovány s nápady jednotlivců, jejich dovednostmi a schopnostmi), transformují se v to nejcennější, ve znalost [23]. Veber [21] pak definuje znalosti jako dynamické systémy zahrnující interakce mezi zkušeností, dovednostmi, fakty, vztahy, hodnotami, myšlenkovými procesy a významem. Jedná se o informace rozšîrené o zkušenost, dovednosti, intuici, osobní představy a mentální modely.

Znalosti mohou nabývat dvou základních podob. Explicitních a tacitních [10, 12]. Zatímco explicitní znalosti jsou v podniku určitým způsobem zaznamenány a udržovány (mohou se vyjádřit slovně, napsat, nakreslit, či jinak znázornit), tacitní znalosti jsou především v hlavách zaměstnanců. Explicitní znalosti se často skladují v informačních systémech společnosti ve formě dat. Tato data jsou velmi lehce přenosná a dají se krást. Tyto znalosti lze nalézt v různých dokumentech, pracovních postupech, statistikách, ročenkách, atd.

Tacitní znalosti definuje např. Bennet a Brockmann jako praktické know-how získané prostřednictvím zkušeností [10]. Bělohlávek zdůrazňuje především vysoce osobní charakter tacitních znalostí. Jsou úzce spjaty s akcí, postupy, rutinami, idejemi, nápady, hodnotami a emocemi. Je obtížné je sdílet a vyjádřit [2]. O některých tacitních znalostech jejich nositel vůbec nemusí vědět, jsou částečně podvědomé.

Nejcennějšími znalostmi jsou tacitní znalosti zaměstnanců, které jsou šířeny a sdíleny v rámci interpersonální komunikace. Při vytváření a využívání tohoto duševního kapitálu spoléhají firmy na „sociální (společenský) kapitál“, jež se vyvíjí tím, jak se lidé vzájemně ovlivňují v průběhu času.

V zájmu podniků by mělo být, aby tacitní znalosti bylo možné přeměnit na znalosti explicitní. Ty jsou totiž daleko snadněji přenosné a dají se velmi rychle rozšiřovat v rámci celé společnosti. Proces přeměny tacitní znalosti ve znalost explicitní se nazývá externalizace. Matošková a Voloch však poukazují na fakt, že explicitní znalost bude tacitní znalosti jen podobná a to $\mathrm{z}$ těchto důvodů [10]: 
Jak bylo zmíněno výše, tacitních znalostí si někdy není zaměstnanec vůbec vědom. Používá je spontánně a získává je nevědomě.

$>$ Nositel znalosti si nemusí být vědom všech jejích vztahů a vazeb.

$>$ Často nelze slovy ani symboly tacitní znalost exaktně popsat.

$>$ Kódy použité pro vyjádření tacitní znalosti může druhý pracovník pochopit jinak a vytvoři si tak vlastní tacitní znalost, která není shodná s původní.

$>\mathrm{V}$ podniku může existovat rivalita a nevole $\mathrm{k}$ šíření znalostí.

$\mathrm{K}$ tomu, aby v podniku docházelo ke sdílení a šíření znalostí, je nutné, aby v podniku fungoval bez potíží trh znalostí. Na tzv. trhu znalostí lze pozorovat dva základní subjekty. Jednak je to prodávající, který určitou znalostí disponuje, a jednak je to kupující, který má o znalost zájem. Další důležitým subjektem je zprostředkovatel, který by měl vědět, kde je možné požadovanou informaci získat. Tuto roli hraje v podniku většinou manažer. Cena znalostí je dána především náklady na její pořízení, její hodnotou a dostupností. Získává-li podnik znalost z vnějšku (tzn. mimo společnost, od externí firmy) platí obvykle za znalost penězi. Dochází-li k získání znalostí z vnitřních zdrojů podniku, většinou kupující za znalost neplatí. Důvodem, proč prodávající znalost poskytne je dle Mládkové [13]:

Reciprocita, kdy pracovník poskytující své znalosti očekává, že v budoucnu za své sdílení dostane jiné znalosti. Může očekávat jiné znalosti od pracovníka, kterému poskytnul své, nebo může očekávat např. od svého manažera, či vedení firmy, že mu bude poskytnuto napřr. užitečné školení.

$>$ Reputace, kdy pracovník poskytující své znalosti očekává vylepšení vlastní image v očích spolupracovníků. Očekává, že k němu ostatní budou vzhlížet, budou se $\mathrm{k}$ němu chovat $\mathrm{s}$ úctou a respektem, budou $\mathrm{k}$ němu chodit pro rady. Pracovník se díky tomu bude cítit užitečný, bude ve firmě pracovat rád.

> Altruismus, kdy pracovník poskytující své znalosti očekává ,jen“ rozšíření znalostí ve společnosti, které by mohly firmě pomoc.

Častým, nežádoucím a velmi nepř́ijemným jevem, se kterým je běžné se setkat v dnešních organizacích, je vědomé zatajování informací. Důvody této situace vystihuje Vymětal [22], který jako hlavní problém vidí především nenabízenou sociální jistotu ze strany firem, která je pak kompenzována tím, že zaměstnanci neposkytují dřive obvyklou a ceněnou loajalitu. Je toho názoru, že ,trh pracovních sil a konkurenční prostředí znalostních pracovníků působí proti sdílení znalostí. Pro znalostního pracovníka totiž vzniká dilema. Jeho cena pro organizaci spočívá $\mathrm{v}$ tom, že je o něm známo jakými nápady, radami, znalostmi a zkušenostmi pomohl spolupracovníkům resp. organizaci při řešení problémů. Dává-li k dispozici své znalosti a sdílí je, pak svou hodnotu znalostního pracovníka postupně ztrácí tím, že spolupracovníci se od něj učí a osvojují si jeho znalosti. Navíc znalostní pracovník riskuje, že spolupracovníci přidají $\mathrm{k}$ jeho znalostem své vlastní a stanou se tak pro organizaci užitečnějšími a potřebnějšími než je on sám. Proč by si měl znalostní pracovník vědomě snižovat svou hodnotu pro zaměstnávající organizaci? Řešením pro pracovníka se tak stává vyvažování míry sdílení a nesdílení znalostí.“ Jasným cílem organizace by tak mělo být motivovat znalostní pracovníky k tomu, aby své znalosti sdíleli. 


\section{Kreativita}

V dosavadní historii lidstva byla naší nejcennější schopností inteligence - schopnost učit se a využívat stávajících vědomostí. V 21. století tomu tak již není. Největší cenu pro nás má tvořivost, schopnost vytvářet vědomosti nové [5].

„Tvořivost spočívá v hledání, přijímání a vytváření netradičních postupů, v nových nápadech, originálních řešeních. Je mimořádně důležitá při vytváření nových kulturních, technických a duchovních hodnot, ve vývoji výrobků, v reklamě, ale i při strategických úvahách. Ale projevuje se také $\mathrm{v}$ každodenních aktivitách většiny lidí. A to $\mathrm{v}$ aktivitách jinak velmi fádních a běžných, nejen v práci, ale i v trávení volného času, v komunikaci... Člověk má tendenci stereotypnost každodennosti určitým způsobem zpestřovat, měnit. Tvořivost je možno považovat za schopnost, později se o ní hovořilo jako o vlastnosti, dnes se často používá výraz, že je možno ji chápat jako postoj ke světu [11].“

Tvořivost je možné rovněž charakterizovat jako tvorbu nových a vhodných nápadů ve všech oblastech lidské činnosti. Kreativita je prvním krokem v tvorbě inovací [3]. Podle Hospodářové je kreativita souhrnem postojů, schopností a procesů, které se vzájemně podporují a ovlivňují. Zdůrazňuje, že všechny tři složky lze rozvíjet. Kreativní postoj tím, že jedinec pozná, kde jsou jeho bariéry kreativity, a postupně je odstraňuje (a především rozvíjí svou toleranci vůči dvojznačnosti, trpělivost, vytrvalost a kladný postoj ke změně). Kreativní schopnosti lze podle ní uvolnit a tím rozvíjet schopnost generování nápadů, citlivost, vnímavost, vědomí vzájemných vazeb a souvislostí. S kreativními procesy a technikami se člověk neustále postupně seznamuje ve své praxi, at' se jedná o brainstorming, či další techniky a postupy $\mathrm{k}$ řešení problémů a hledání nových nápadů a cest rozvoje [8].

Csikszentmihalyi charakterizuje tvořivost jako jeden z nejvýznamnějších základů smysluplnosti života. Vyzdvihuje především její pestrost, oživení a novost, kterou přináší do každodenního života, který by byl bez ní př́iliš fádní. Zároveň zastává názor, že pro tvořivé osobnosti je typické kromě vybočování ze stereotypů současně i vybočování ze stereotypů pohlaví. To znamená, že tvořiví muži se projevují větší citlivostí a sníženou agresivitou, což je většinou typické pro ženy a ženy se naopak projevují větší dominancí a nepoddajností, které jsou typické pro muže [4].

Zatímco McKinnon považuje kreativitu za originalitu v myšlení a novost $\mathrm{v}$ př́stupu k problémům, Barron chápe tvořivost jako osobnostní rys, jako součást osobnostní struktury [11]. Jiní autoři vidí podstatu tvořivosti v motivaci. Např. Maslow vidí kreativitu jako životní podstatu, která je maximem sebeuskutečnění osobnosti [7]. Dle profesorky Teresy Amabile je kreativita definována jako generování nových a vhodných myšlenek, inovace potom chápe jako celý proces implementování těchto nápadů do podnikové praxe. Tvořivost podle ní spočívá právě v motivaci. Zatímco vyzdvihuje vnitřní motivaci, která napomáhá kreativitě, vnější motivaci pak považuje za nepříznivý činitel tvưrčí činnosti, jelikož cíl vymyšlení nového produktu se mění na cíl dosáhnout odměny [23].

Další skupina autorů se přiklání k nutnosti kvalitních vztahů na pracovišti. Adair charakterizuje tvořivé myšlení jako intenzivně společenskou aktivitu. Dále zmiňuje, že lze těžce přemýšlet bez stimulů a vstupních dat, které se k pracovníkům dostávají z okolí, myslí ostatních lidí. Své myšlenky si lidé vyjasňují a ověřují v rozhovorech s ostatními. Má-li člověk kreativně přemýšlet, potřebuje nepřetržitý přísun podněcujících sociálních kontaktů. Buduje tak na výsledcích ostatních lidí, využívá tak jejich prrínos a ostatní zase profitují 
na něm a jeho myšlenkách [1]. Stejně tak i Osborne vidí mezilidské vztahy jako stěžejní podmínku kreativního myšlení [11].

\section{Pracovní podmínky vedoucí k podpoře kreativního myšlení}

Chceme-li, aby v podniku mohli být pracovníci kreativní a nebáli se přijít s novými myšlenkami, musí management definovat a prosazovat tzv. proinovační fïremní kulturu. Firemní kulturu definovala řada autorů, např. Pfeifer [17], dle kterého je firemní kultura souhrn představ, př́istupů a hodnot ve firmě všeobecně sdílených a relativně dlouhodobě udržovaných. Nebo Palán [15], jež definuje firemní kulturu jako „podnikové normy, hodnoty, zvyky, obyčeje, tradiční vzorce chování, styl řízení, styl mezilidských vztahů, vztah ke vzdělávání, způsoby řešení problémů, metody práce, charakterizující prrijatelnost a neprrijatelnost určitého chování. Podniková kultura dle něj reprezentuje podnik i v oblasti public relations. Za podnikovou kulturu považuje i to, co se vyhlašuje pomocí hesel, ale i vztahy a život, který v podniku skutečně existuje, hodnoty, které v podniku reálně existují, myšlení, které tvoří základ jednání všech pracovníků podniku a které se v jednání každodenně projevuje. Podniková kultura se tak stává činitelem, který sbližuje stanoviska zaměstnanců a firmy, přispívá k identifikaci (ke ztotožnění) zaměstnanců s firmou.“

Pro podnícení kreativního myšlení je podle Petříkové [16] nutné, aby zaměstnanec nejdříve uvěřil, že disponuje schopnostmi, které mohou být prrínosem jak pro firmu, tak pro něj samotného v podobě ovlivnění odměn a uspokojení z práce. Také musí být přesvědčen, že společnost jde vstříc dobrým nápadům zaměstnanců a bude je podporovat. Jako třetí faktor uvádí Petř́ková nezbytnost přesvědčení zaměstnance o spravedlivém systému odměňování a motivace také formou neformálního uznávání nositelů znalostí a inovací. Profesorka Teresa Amabile definovala 6 základních podmínek podnikového prostředí, které stimuluje tvořivost: vysoká míra autonomie, dostatečné zdroje, organizační podpora, týmová podpora, manažerská podpora a výzva.

Autonomií pracovníků se obecně chápe volnost v konání, v jejímž rámci mohou zaměstnanci uplatnit své schopnosti. Stimuluje to smysl pro zodpovědnost. Pracovníci tak mají pocit kontroly nad vlastními nápady. Stimulem pro kreativní myšlení je výzva. V rámci tohoto článku budeme výzvou rozumět práci na složitých problémech, které zatím nemají objasnění a pro ostatní pracovníky jsou neřešitelné. Čím významnější je úkol, tím více přináší zaměstnanci pocit, že vykonává něco důležitého, co příznivě ovlivňuje i jeho pracovní motivaci.

$\mathrm{V}$ rámci podnikových týmů je nutná týmová podpora. Nejen v rámci týmu, ale i v celé společnosti je nutné navodit pocit vzájemné důvěry, otevřenosti a respektu. Pracovníci se nesmí bát přijít s novým návrhem z toho důvodu, že se jim někdo vysměje, či se ztrapní. Pouze pokud v organizaci, či týmu panuje vzájemná důvěra, nemusí se pracovníci bát projevit svůj názor, jít s někým do konfliktu (tam, kde je vzájemná důvěra, respekt a úcta, mohou být konflikty i žádoucí a užitečné), otevřeně komunikovat a projevit nesouhlas. Pro takovou organizaci je typické, že jsou lidé spontánní, tvořiví a nebojí se riskovat. Nebojí se přiznat vlastní dílčí neúspěchy, či pochybení a snaží se z nich poučit.

Management podniku by měl své týmy podporovat. Každý tým by měl mít svého přímého nadřízeného, který sice zadá úkol, ale v rámci týmu ponechá volnost a efektivně s týmem komunikuje a chrání ho před rušivými vlivy. 
Nespornou podmínkou inovativní firmy je dostatek zdrojů. Kromě kvalitních lidských zdrojů, o kterých je tento článek, je třeba mít dostatek zdrojů finančních a kapacitních. Dủležitou roli bude hrát také flexibilita rozhodovacího procesu při zavádění nových výrobků na trh. Právě čas hraje klíčovou roli a rozhoduje o tom, zda-li firma bude jediným výrobcem na trhu a bude tak moci využívat strategii prémiových cen, nebo se zařadí jen mezi firmy vyrábějící podobný výrobek.

Proinovační prostředí firmy podporují rovněž tzv. „Dobré nápady“. Existuje nespočet firem, které tuto politiku následují, včetně společnosti Alfa s.r.o. Dobré nápady nevznikají pouze u specializovaných kreativních skupin, nýbrž v celém podniku. Operátorem výroby začínají a generálním ředitelem končí. Právě zapojení zejména výrobních operátorů dává firmě ohromnou sílu. Každý člověk zná své pracoviště nejlépe, ví, kde se skrývají nebezpečí úrazu či potenciální nehody (tudíž jsou tyto nápady vhodné pro politiku BOZP), zároveň se snaží sám sobě ulehčit práci, a tak je přirozené, že hledá věci, díky kterým by se dal např. ušetřit čas určité aktivity. Pokud takovou myšlenku operátor, nebo kdokoliv jiný odevzdá, dostane jen za nápad menší odměnu, bez ohledu na to, bude-li se realizovat, či nikoliv. Nebude-li se nápad realizovat, dostane pracovník vyrozumění, proč tomu tak není. Většinou se jedná o finančně náročné akce, kdy je třeba vysokých investic, které ale nepřinesou žádoucí efekt např. v podobě určité návratnosti. Pokud se bude nápad realizovat, nejen že zaměstnanci bude umožněno, aby sám svůj nápad realizoval (bude-li to v jeho silách), ale postupuje s dobrým nápadem do dalších kol, kde na konci roku může např. vyhrát určitou finanční částku, či zájezd pro celou rodinu do zahraničí. Má-li firma více výrobních závodů, často se stává, že pracovníci mezi sebou soutěží, kdo takových nápadů bude mít víc, kdo jich více implementuje, a které budou přínosnější (stejná soutěživost nastává v rámci výrobního závodu, který disponuje několika výrobními linkami). To je to, čeho chce podnik dosáhnout. Pro výrobní operátory je tato politika rovněž př́iležitostí dostat se na vyšší hierarchické místo. Uvidí-li podnik, že má schopné a kreativní operátory, kteří mají výborné technické myšlení, bude se je snažit využívat např. jako techniky.

Jak je zmíněno již výše, dobré nápady by neměly přicházet jen od výrobních operátorů, nýbrž by měly být prosazovány napříč celým podnikem. V rámci THP pracovníků a managementu je otázkou, do jaké míry jde o dobrý nápad a do jaké míry je vlastně dobrý nápad náplní práce zaměstnance. Vzhledem k tomu, že takový pracovník je v jiné platové stupnici a v jiném společenském postavení, očekává se od něj rovněž jiný stupeň dobrých nápadů. Takový dobrý nápad by měl vést nap̌r. ke zlepšení činnosti druhých oddělení, měl by vést ke zlepšení klima v dané společnosti, či ke zlepšení výsledku hospodaření.

\section{Překážky kreativního myšlení uvnitř podniku}

Překážky, které tlumí kreativní myšlení v podniku, mohou být rozděleny do tří rovin. První rovinu představují potíže vyvolané organizací, druhou problémy, vyvolané manažery a třetí jsou potíže uvnitř pracovního kolektivu. Často se však jednotlivé roviny navzájem prolínají a je velmi obtížné je od sebe rozeznat a kvantifikovat. Záleží, na jaké hierarchické úrovni se problémy vyskytují zda-li mají globální charakter, či budou mít dopad např. jen na místní business unit.

Problémy organizace jsou globálnějšího charakteru a vyplývají z firemní strategie. Tyto nedostatky dopadají na celou organizaci, nikoliv jen na jednotlivé samostatné obchodní 
jednotky. Častou chybou bývá prosazování krátkodobých cílů na úkor dlouhodobých. Obzvlášt' citlivé to může být $\mathrm{v}$ dnešní době, kdy by se podnik měl snažit působit na co největší trh. Není tedy výjimkou, když hlavním cílem podniku je maximální zisk, který ovšem může být dosažen právě na úkor nižších nákladů spojených s výzkumem a vývojem, nebo marketingem. Tím, že bude podnik snižovat náklady na výzkum a vývoj, bude se zbavovat svých vysoce kvalifikovaných pracovníků. Zároveň bude-li snižovat náklady na marketing, bude se dostávat z povědomí zákazníků. Tento tah by se v budoucnu podniku mohl vymstít, jelikož na trhu budou další hráči, kteří se budou snažit oslovit a přetáhnout zákazníky a vysoce vzdělané pracovníky naší firmy.

Dalším nebezpečím může být neochota riskovat a podstupovat určitou míru rizika. Bud' se tak stane kvůli averzi managementu k riziku, nebo se k tomu organizace uchýlí v okamžiku, kdy bude mít dobré hospodářské výsledky a management tak nabude dojmu, že vše dělá, tak jak má a že nejlepším řešením bude ,nedělat nic“ a udržovat svou pozici na trhu tím, že bude pokračovat v tom, co dělal dosud. Rovněž se tak může stát po nepovedených projektech, které podnik stály značnou část peněz.

Za největší problém současných podniků lze ovšem považovat nesdílení informací mezi pracovníky. Zjevné je to $\mathrm{v}$ případě, kdy přijde do zaměstnání nový pracovník, přičemž spolupracovník, který ho zaškoluje, má monopol na znalosti, které ve společnosti nabyl a může si vybírat, které novému pracovníkovi sdělí a které si nechá pro sebe. Tuto bariéru je nutné odstranit a zajistit to, aby znalosti pracovníků byly znalostmi firmy.

Proč dělat věci jinak, když jdou dělat složitěji? Většinou se takto ironicky ptají lidé, kteří přijdou do nového prostředí, kteří ještě nezapadli do tzv. ,proudu přihlížejících“, neboli těch, kteří se podřídili a smírili s tím, jakým zpo̊sobem firma funguje. Nejčastěji se tento problém projevuje u komunikace, kdy mezi jednotlivými meetingy a znovu projednáním návrhu proběhne dlouhá doba, během níž se nic neděje a je tím pádem nežádoucí. Manažeři mají často tendence odpovídat na otázku, proč se věci nedějí jinak, tak, že takovým způsobem již firma funguje pět let a jiné to nebude. Přičemž, když se každý zamyslí, jak rychle se mění prostředí uvnitř ale hlavně vně podniku, je to zarážející. Jít s proudem je většinou pohodlnější než jít proti němu. A manažer, který si není jistý sám sebou, proti „nikomu a ničemu nebojuje“".

Pokud komunikace uvnitř firmy není dostatečně rychlá a efektivní, může firma vlastnit nespočet kreativních pracovníků, ale jejich myšlenky nebudou nikdy světu známy. V takto rigidních firmách bývá obvyklé, že se s novými nápady chodí nejdříve za manažerem a teprve ve chvíli, kdy se nápad zalíbí jemu, postoupí jej dále. Takže pokud se manažerovi bude nápad líbit, bude ho prosazovat na další poradě vedení, ale otázkou například je, bude-li umět nápad prezentovat a prosadit takovým způsobem, jako vlastník tohoto nápadu. Jaká je jeho vyjednávací síla $v$ rámci managementu? Zároveň $\mathrm{s}$ každou další linií roste šum při interpretování nápadu a z toho vyplývá nebezpečí jeho degradace. Rovněž to znamená, že nebude-li se nápad líbit manažerovi, pro firmu je to samé, jako by žádný nápad nebyl. Nejen, že z toho nebude profitovat firma, ale ani samotný pracovník.

Problém může představovat i manažer, který má tendence ve všem hledat chyby a negovat vše, co se dá. Tito manažeři jdou do detailů, problémy hledají vždy a všude a nenechají nit suchou. S podřízeným nesouhlasí jen proto, že si o sobě myslí, že jsou vševědoucí. Myslí si, že přehnaně kritické připomínky jsou výrazem perfekcionismu. Říci "ano" je pro ně výrazem pokleslého standardu. 
Dalším problémem je přisvojování si zásluh a nápadů manažerem. Manažeři musí být velmi opatrní v tom, jakým způsobem s nápady nakládají a jakým způsobem je interpretují. Každého dobrého nápadu by si společnost měla vážit. Obzvlášt' ceněné by měly být nápady vznikající např́ič jednotlivými odděleními. Pracovník, nebo manažer jiného oddělení může najít určité mezery v procesech, či jednání druhých oddělení kolikrát i snadněji, než manažer vlastního oddělení, který ty nedostatky nevidí. Často však v podnicích vítězí ješitnost manažerů, kteří si nenechají do své práce nikým mluvit, ani nejbližšími kolegy. S tím je spojen problém další a to častá neznalost jiných přístupů. To, co bylo před dvaceti lety, nemusí platit dnes, existují jiné metody, které jsou schůdnější. Není třeba lpět na starých „dobrých“ způsobech.

Velmi frekventovanou hodnotou, kterou firmy prosazují, je vzdělávání svých zaměstnanců. Potřeby vzdělávání jsou ale u každého člověka individuální. Jeden si pod pojmem firemního vzdělávání představí navštěvování kurzů např. Anglického jazyka. Další by se rád zdokonaloval v rámci softwaru, který v práci používá a je pro něj klíčový. Jiný by rád zlepšoval např. své měkké dovednosti. A poslední bude toho názoru, že všechny výše zmíněné (nebo jím vybrané a preferované) činnosti může dělat ve svém volném čase, ale stál by o to, kdyby v rámci svého samostudia (napřr. při studiu vysoké školy) dostal tři dny dovolené navíc. Jak je vidět, potřeby každého zaměstnance jsou různé, velmi často proměnlivé, a proto je manažer musí sledovat a pravidelně revidovat. Na základě vzájemné diskuze a pravidelného hodnocení by měl manažer spolu s pracovníkem dojít k ideálnímu vzdělávacímu plánu, který by byl jak ve prospěch firmy, tak ale i v zájmu zaměstnance.

Častým problémem je také trestání kreativních pracovníků spojené s neúspěchem projektu. V této fázi je třeba být velmi opatrný. Je třeba si klást celou řadu otázek, např.: Kde je hlavní příčina neúspěchu? Jaké faktory vně podniku se změnily? Jaké faktory uvnitř podniku se změnily? Probíhala komunikace v rychlém sledu? Co se dalo udělat lépe? Co musíme udělat do budoucna lépe? Kdo pochybil? Bylo to poprvé? Dalo se chybě předejít a předvídat ji? Jak a kdy? Pokud totiž bude docházet k trestání pracovníků, kteří jsou nositeli myšlenek, budou mít obavy chodit s průlomovými nápady, jelikož ty s sebou nesou největší riziko. Proto, aby je nestihl další trest, se budou chovat konzervativněji, což může být pro podnik nežádoucí.

Bohužel, mezilidské vztahy nelze nadiktovat, vznikají spontánně a vyvíjí se. V negativně laděných pracovních skupinách bude docházet často ke konfliktům a sebe prosazování. Takový kolektiv trpí vzájemnou antipatií a nechutí ke spolupráci. Velmi zde záleží na osobnosti manažera, jeho chování a způsobu řešení různých problémů.

\section{Výzkum provedený ve společnosti}

Výzkum ve společnosti probíhal metodou neřízeného rozhovoru, během nějž se autor článku individuálně setkal celkem s patnácti pracovníky. Cílovou skupinou byli THP pracovníci různých oddělení a cílem rozhovorů bylo zjistit, zda-li se výše uvedené př̌kážky kreativního myšlení v podniku vyskytují, či nikoliv.

Ve společnosti Alfa s.r.o. byl potvrzen výše zmíněný problém nesdílení informací. Z celkových patnácti dotázaných tento problém zaregistrovalo 14 zaměstnanců. Většina dotázaných uvedla jako nejpravděpodobnější důvod strach ze ztráty zaměstnání v důsledku lepších znalostí spolupracovníka. Rovněž se potvrdilo, že mnohdy se problémy řeší složitěji, 
než by bylo nutné (domnívá se tak 8 z 15 dotázaných). Těchto 8 pracovníků, kteří vidí mezery v řešení nastalých situací, lze rozdělit do dvou skupin. První skupina své nadřízené o možnosti jednoduššího řešení informuje a je většinou na manažerech, zda si zvolený způsob prosadí u svých nadřízených (zde vzniká další problém, kdy manažer zamítne elegantnější řešení z toho důvodu, že se zkrátka úkoly řešily tímto způsobem a proto se tak budou řešit i nadále). Druhá skupina pracovníků o možnosti jednoduššího řešení své manažery neinformuje, jelikož se domnívá, že rychlejší a snadnější bude splnit to, co je určitým způsobem požadováno, než jednat o novém řešení, které by nebylo doceněno (většinou na základě minulých zkušeností - zde podobnost se Skinnerovou teorií).

Se vzděláváním ve společnosti nebyla spokojena polovina pracovníků. Kromě možnosti výuky cizích jazyků, která je organizována společností ve spolupráci se zaměstnanci (zaměstnanec si sám platí část výuky), neexistuje pro pracovníky některých oddělení žádná jiná možnost vzdělávání. Uvítali by především kurzy v rámci softwaru, který firma používá a pro činnost pracovníků je klíčový. S mezilidskými vztahy na pracovišti nebyla spokojena třetina dotázaných. Kromě problému nesdílených informací, který je uveden výše, nebyli pracovníci spokojeni především s kolegy, kteří na podobné pozici neodvádějí takové výkony, které se domnívají, že odvádějí oni a jsou přesto podobně hodnoceni (ve společnosti je ale zákaz sdílení informací o platech, proto se jedná ze strany pracovníků znovu o domněnku). Rovněž je velmi kritizován systém odměňování. Vzhledem k tomu, že fixní plat roste s lety, které pracovník ve společnosti odpracuje, neodvíjí se mzda pracovníka od skutečného výkonu, což je často demotivující.

O návrh na zlepšení činností jiných oddělení se pokusila pouze třetina dotázaných, přičemž jen jeden pracovník se setkal s odmítavým postojem manažera, který byl přesvědčen, že oddělení i přes opakované připomínky vykonává činnosti dle nejlepších možných postupů a nepřistoupil na předkládaný návrh. Hypotéza, že manažeři nejsou přístupní novým řešením pracovníků jiných oddělení, se tedy plně nepotvrdila, nicméně je vidět, že tento problém ve společnosti rovněž existuje. Pro potvrzení, či vyvrácení by bylo nutné provést výzkum $\mathrm{s}$ širším portfoliem respondentů.

\section{Závěr}

Znalosti hrají v současných podnicích neustále důležitější roli. Jsou to právě znalostní pracovníci, kteří tvoří firemní bohatství v podobě nových nápadů, znalostí nových přístupů a metod. Jedním z největších problémů současných podniků je nesdílení informací. Podniky si tento fakt většinou uvědomí pozdě, a to až ve chvíli, kdy takového zaměstnance ztratí. Zjistí, že nemají adekvátní náhradu za pracovníka a že jeho znalostmi nikdo jiný nedisponuje. Podnik tak musí znovu investovat do vzdělání dalšího pracovníka, který práci přebírá. To ale v praxi znamená řadu dalších výdajů a zároveň je třeba zohlednit fakt, že určitý čas trvá, než se pracovník ve firmě ,usadí“ a začne podniku přinášet přidanou hodnotu. Proto by mělo být v zájmu podniku zajistit to, aby se v podniku znalosti sdíleli. Je nutné nastavit motivační systém takovým způsobem, aby motivoval „prodávajícího“ (v podobě člověka, který znalost vlastní), aby své znalosti rozšiřoval dál. Zároveň je nutné, aby manažeři v podniku věděli, kdo a jakými znalostmi v podniku disponuje, měli by totiž fungovat v roli zprostředkovatele, tedy člověka, který svému týmu dokáže pomoci ve chvíli, kdy jeho člen bude určité znalosti potřebovat. 
V rámci tohoto článku byly vyzdvihnuty atributy, které kreativní myšlení podněcují a ty, které ho tlumí. Do první skupiny neodmyslitelně patří vzájemná důvěra, která umožňuje efektivní komunikaci uprostřed týmu, a tím pádem i vzájemnou týmovou podporu. Zároveň je nutné dát zaměstnancům určitou autonomii, svobodu, aby měli pocit kontroly nad svými nápady. Manažer by měl tým podporovat a chránit před negativními vlivy. Rovněž je pro uplatnění nápadů nutné mít dostatečné zdroje. Negativně laděné pracovní skupiny kreativní myšlení tlumí. V takových skupinách existuje velká soutěživost (až nezdravá), prosazování sama sebe a dochází v nich často ke konfliktu. Chybou podniků je prosazování krátkodobých cílů na úkor dlouhodobějších a vyhýbání se riziku. Často je slabým článkem právě manažer, který může svým chováním demotivovat celý kolektiv.

Výzkum ve společnosti Alfa s.r.o. probíhal formou neřízeného rozhovoru s patnácti THP pracovníky. Cílem bylo potvrdit, či vyvrátit, zda-li se faktory, které působí proti kreativnímu myšlení, objevují i v této společnosti. Problém nesdílených znalostí potvrdilo 14 z patnácti dotázaných. Osm z patnácti dotázaných je přesvědčeno, že některé situace/procesy se řeší složitěji, než by se řešit musely. Stejný počet dotázaných je spokojeno se vzděláváním ve společnosti. Zbytek by preferoval jiný druh vzdělávání, než je ve společnosti nabízeno. Nespokojenost je zřejmá u odměňovacího systému, který pracovníky dostatečně nemotivuje. Plat se zvyšuje s odpracovanými lety, nikoliv dle skutečných výkonů.

Pro potvrzení, či vyvrácení závěrů autor v dalším průběhu studia provede anonymní podrobnější výzkum dotazníkovou metodou ve více podnicích, kde budou osloveni zaměstnanci na všech úrovních.

\section{Použitá literatura:}

[1] ADAIR, J. Efektivní inovace. 1. vyd. Praha: Alfa Publishing, 2004, 240 s. ISBN 8086851-04-4

[2] BĚLOHLÁVEK, F., KOŠTAN, P., ŠULER, O. Management, Brno: Computer press, c2006, 724 s. ISBN 80-251-0396-X

[3] CHENG, CHAU, AU. Does knowledge reuse make a creative person more creative?, Science direct, Decision Support Systems 45 (2008) 219-227

[4] CSIKSZENTMIHÁLYI, M., Creativity: flow and the psychology of discovery and invention, New York : Harper Perennial , 1997, 456 s.

ISBN 978-0-06-092820-9

[5] DACEY, J.S., LENNON, K.H. Kreativita, Grada Publishing, 2000, 250 s. ISBN 80-7169-903-9

[6] DRUCKER, P. F. Inovace a podnikavost, Praha: Management Press, 1993, 266 s. ISBN 80-85603-29-2

[7] HLAVSA, J. Psychologické základy teorie tvorby, Praha : Academia, 1985, $353 \mathrm{~s}$.

[8] HOSPODÁŘOVÁ, I. Kreativní management v praxi, Praha : Grada, 2008, 130 s., ISBN 978-80-247-1737-1

[9] KOŘÍNEK, T., Vliv neurčitost, nejasnosti, nejistoty a složitosti na rozhodování společnostní, SCIENTIFIC PAPERS OF THE UNIVERSITY OF PARDUBICE, SPECIAL EDITION, 2009, 45-51 ISBN 978-80-7395-209-9; Available from: http://www.upce.cz/fes/veda-vyzkum/fakultni-casopisy/scipap/archiv/e-verzesborniku/2009/scipap-c-se.pdf 
[10] MATOŠKOVÁ J., VOLOCH J., Význam sdílení znalostí pro inovační rozvoj firmy, Podmínky podnikatelské úspěšnosti inovace, 2006, 53-58, available from: http://www.svses.cz/skola/akce/konf/inovace06/texty/sbornik.pdf

[11] MIKULÁŠTÍK, M., Tvořivost a inovace v práci manažera, Praha : Grada, 2010, 207 s. ISBN 978-80-247-2016-6

[12] MLÁDKOVÁ, L., Management znalostních pracovníků, C. H. Beck, Praha, 2008, 128 s. ISBN 978-80-7400-013-3

[13] MLÁDKOVÁ, L., Management znalostí v praxi, 1. Vydání, Praha: Professional Publishing, 2004, 155 s. ISBN 80-86419-51-7

[14] MUŠKA, M., KRÁLÍK, J., Otevřená inovace - přístup překračující známé hranice, SCIENTIFIC PAPERS

OF THE UNIVERSITY OF PARDUBICE, SPECIAL EDITION, 2009, 79-86 ISBN 978-80-7395-209-9

Available from: http://www.upce.cz/fes/veda-vyzkum/fakultni-casopisy/scipap/archiv/everze-sborniku/2009/scipap-c-se.pdf

[15] PALÁN, Z. Lidské zdroje, Praha: Academica, 2002. 280 s. ISBN 80-200-0950-7

[16] PETŘÍKOVÁ, R. aj. Lidé v procesech řízení. 1. vyd. Professional Publishing, 2007, 216s. ISBN 978-80-86946-28-3

[17] PFEIFER, L., UMLAUFOVÁ, M.: Firemní kultura, Praha: Grada, 1993, 130 s. ISBN 80-7169-018-X

[18] SCHUMPTER, J. A. Teória hospodarského vývoja, Bratislava, Pravda, 1987, 478 s.

[19] SMITH, D. Designing an innovative Britain, ESRC The Edge (21) (2006), available from:

http://www.esrc.ac.uk/_images/The\%20Edge\%2021_tcm8-8228.pdf

[20] URBANEC, J., URBANCOVÁ J. The survey of tacit knowledge sharing in organisation, SCIENTIFIC PAPERS OF THE UNIVERSITY OF PARDUBICE, 19, 2011, 220-231, ISSN 1804-8048 (Online), available from: http://www.upce.cz/fes/vedavyzkum/fakultni-casopisy/scipap/posledni-obsah.pdf

[21] VEBER, J. a kol. Management: základy, prosperita, globalizace, Praha: Management Press, 2000, 700 s. ISBN 80-7261-029-5

[22] VYMĚTAL, J., Některé problémy transformace firemního informačního střediska na středisko znalostní. INFORUM 2007 : 13. konference o profesionálních informačních zdrojích Praha, 22.-24.5.2007. http://www.inforum.cz/pdf/2007/vymetal-jan.pdf

[23] ŽÁK, P. Kreativita a její rozvoj. Brno, Computer press, 2004, 315 s. ISBN 80-251-0457-5

\title{
JEL O31
}

\author{
Ing. Jan Žahour \\ Doktorand \\ Ústav ekonomiky a managementu \\ Univerzita Pardubice \\ Fakulta ekonomicko-správní \\ Studentská 84 \\ 53210 Pardubice \\ jzahour@seznam.cz
}

